Pendekatan Hermeneutika Dalam Ilmu Tafsir...

\title{
PENDEKATAN HERMENEUTIKA DALAM ILMU TAFSIR
}

\author{
Ummi Inayati \\ Fakultas Tarbiyah STAI Attanwir Bojonegoro \\ ienayaazzaheen@gmail.com
}

\begin{abstract}
This article is a qualitative research research literature on hermeneutics in interpretation. This article was written to answer how hermeneutic approaches in the science of interpretation and hermeneutic perspective on the Qur'an. As a new methodology for the study of the holy book, the existence of hermeneutics is inevitable in the world of the Holy Qur'an. The mushrooming of a variety of contemporary interpretative literature that offers hermeneutics as a variable method of understanding the Koran shows how attractive the hermeneutic is indeed. Hassan Hanafi in his Religious Dialogue and Revolution states that Hermeneutics is not just a science of interpretation or theory of understanding, but also means a science that explains the acceptance of revelation from the word level to the world level. Knowledge of the process of revelation from letters to reality, from logos to praxis and also the transformation of revelation from the mind of God to human life.
\end{abstract}

Keywords: Hermeneutics, Tafsir, al-Qur'an

\begin{abstract}
Abstrak
Artikel ini merupakan penelitian kualitatif dengan penelurusan literatur tentang hermeneutika dalam ilmu tafsir. Artikel ini ditulis untuk menjawab bagaimana pendekatan hermeneutika dalam ilmu tafsir dan perspektif hermeneutika terhadap al-Qur'an. Sebagai sebuah tawaran metodologi baru bagi pengkajian kitab suci, keberadaan hermeneutika pun tidak bisa dielakkan dari dunia kitab suci al-Qur'an. Menjamurnya berbagai literature Ilmu Tafsir kontemporer yang menawarkan hermeneutika sebagai variabel metode pemahaman al-Qur'an menunjukkan betapa daya tarik hermeneutika memang luar biasa. Hassan Hanafi dalam tulisannya Religious Dialogue and Revolution menyatakan bahwa Hermeneutik itu tidak sekedar ilmu interpretasi atau teori pemahaman, tetapi juga berarti ilmu yang menjelaskan penerimaan wahyu sejak dari tingkat perkataan sampai ke tingkat dunia. Ilmu tentang proses wahyu dari huruf sampai kenyataan, dari logos sampai praksis dan juga transformasi wahyu dari pikiran Tuhan kepada kehidupan manusia.
\end{abstract}

Kata Kunci : Hermeneutika, Tafsir, al-Qur'an.

Falasifa, Vol. 10 Nomor 2 September 2019 | 68 


\section{Ummi Inayati}

\section{PENDAHULUAN}

Al-Qur'an merupakan petunjuk dan rahmat bagi sekalian alam, serta mampu membimbing umat Islam dimanapun dan kapanpun. Namun kenyataannya, untuk mendapatkan petunjuk dan rahmat al-Qur'an bukan pekerjaan mudah dan membutuhkan segala upaya intelektual dan metodologi penafsiran yang cocok. Dengan metodologi yang sesuai al-Qur'an baru dapat diajak berdialog dalam suasana bagaimanapun dan dimanapun. ${ }^{1}$ Pada dasarnya metodologi penafsiran telah dibentuk oleh ulama-ulama salaf sebagai upaya mereka mendialogkan al-Qur'an dengan konteks mereka. Ketika metodologi itu dibawa ke konteks yang berbeda, maka tidak mampu lagi mendialogkan al-Qur'an sebagaimana kebutuhan konteks yang baru. Jadi, untuk menjadikan al-Qur'an terus berbicara maka membutuhkan metodologi baru yang bisa mengakomodasi perkembangan zaman sehingga al-Qur'an menjadi elastis dan fleksibel. ${ }^{2}$

Heremeneutika tergolong disiplin ilmu baru dalam diskursus ulum al-Qur'an. Kehadirannya mengundang kecurigaan dan tanda tanya di kalangan para pemikir muslim terutama dari golongan konserfatif. Tidak jelas alasan dari penolakan ini, namun balutan emosional dan sentimental yang berlebihan terhadap Barat ditengarai sebagai salah satu penyebabnya. Karena hermeneutika lahir dan tumbuh di Barat. ${ }^{3}$ Cara kerja hermenutika tidak jauh berbeda dengan tafsir dalam Islam bahkan sebagaian sarjana muslim menyebutnya sebagai suatu yang sama namun dalam balutan baju yang berbeda. Memang benar hermeneutika dan tafsir tidak dapat dipersamakan dalam semua hal namun keduanya memiliki peran yang sama yaitu membantu pembaca memperoleh pemahaman yang subyektif mungkin dari teks yang ia baca. ${ }^{4}$

\section{PEMBAHASAN}

\section{A. Pengertian Hermeneutika Ilmu Tafsir}

Sebenarnya tidak mudah untuk memberikan defenisi yang tepat dan akurat tentang hermeneutika hanya dalam rentetan satu-dua kalimat. Kata ini sering diasosiasikan dengan nama salah seorang dewa Yunani, Hermes, yang dianggap sebagai utusan para dewa di

\footnotetext{
${ }^{1}$ Kurdi.Hermeneutika Al-Qur'an dan Hadis.(Yogyakarta: Sukses Offset. 2010) hlm.59

${ }^{2}$ Ibid. hlm. 59

${ }^{3}$ Ibid. hlm. 85

${ }^{4}$ Ibid. hlm. 85
} 
Pendekatan Hermeneutika Dalam Ilmu Tafsir...

langit untuk membawa pesan kepada manusia. ${ }^{5}$ Pengasosiasian Hermeneutik dengan

Hermis ini saja secara sekilas menunjukkan adanya tiga unsur yang pada akhirnya menjadi variable utama pada kegiatan manusia dalam memahami, yaitu:

1. Tanda, pesan atau teks yang menjadi sumber atau bahan dalam penafsiran yang diasosiasikan dengan pesan yang dibawa oleh Hermes.

2. Perantara atau penafsir (Hermes).

3. Penyampaian pesan itu oleh sang perantara agar bisa dipahami dan sampai kepada yang menerima.

Beberapa kajian menyebut bahwa Hermeneutika adalah "proses mengubah sesuatu atau situasi ketidaktahuan menjadi tahu dan mengerti". 6 Definisi ini agaknya definisi yang umum, karena jika melihat terminologinya, kata Hermeneutika ini bisa didefinisikan ke dalam tiga pengertian:

1. Pengungkapkan pikiran dalam kata-kata, penerjemahan dan tindakan sebagai penafsir.

2. Usaha mengalihkan dari suatu bahasa asing yang maknanya gelap tidak diketahui ke dalam bahasa lain yang bisa dimengerti oleh si pembaca.

3. Pemindahan ungkapan pikiran yang kurang jelas, diubah menjadi bentuk ungkapan yang lebih jelas. $^{7}$

Secara lebih luas Hermeneutika didefenesikan oleh Zygmunt Bauman sebagai upaya menjelaskan dan menelusuri pesan dan pengertian dasar dari sebuah ucapan tulisan yang tidak jelas, kabur, remang-remang dan kontradiktif yang menimbulkan kebingungan bagi pendengar atau pembaca. ${ }^{8}$

\footnotetext{
${ }^{5}$ Dalam agama Islam, Nama Hermes sering diidentikkan dengan Nabi Idris, orang yang pertama kali mengenal tulisan, teknik dan kedokteran.Di kalangan Mesir Kuno, Hermes dikenal sebagai Thor, sementara dikalangan Yahudi dikenal sebagai Unukh dan di kalangan masyarakat Persi Kuno sebagai Hushang. Lihat Sayyed Hossein Nashr, Islamic Studies: Essay on Law and Society, (Beirut: Libreirie Du Liban, 1969), hlm. 64

${ }^{6}$ Richard E. Palmer, Hermeneutics: Interpretation Theory in Schleiermacher, Dilthey, Heiddeger, and Gadamer, (Evanson: Northwestern University Press, 1969). Hlm. 3

${ }^{7}$ F. Budi Hardiman, "Hermeneutik; Apa itu?" dalam Basis, XL, no.3, 1990. Hlm.3

${ }^{8}$ Zygmunt Bauman, Hermeneutics anda Social Sciences, (New York: Columbia University Press, 1978). Hlm. 7
}

Falasifa, Vol. 10 Nomor 2 September 2019 | 70 


\section{Ummi Inayati}

Asumsi paling mendasar dari hermeneutika ini sebenarnya telah jelas, yaitu 'adanya pluralitas dalam sebuah pemahaman manusia'.Pluralitas yang dimaksud sifatnya niscaya, karena pluralitas tersebut bersumber dari keragaman konteks hidup manusia. Sebenarnya, kesadaran akan pluralitas pemahaman yang disebabkan oleh perbedaan konteks ini telah muncul sejak lama dalam tradisi intelektual-filosofis, misalnya dalam pembedaan antara nomena-fenomena dari Immanuel Kant. Menurut Kant, ketika seorang berinteraksi dengan sesuatu dan kemudian memahaminya lalu menghasilkan sebuah pengetahuan tentang sesuatu tersebut, tidak pernah seseorang itu mampu memproduksi pengetahuan tentang sesuatu tersebut sebagai sesuatu yang otentik sebagaimana adanya, namun pengetahuan yang dihasilkan adalah pengetahuan tentang sesuatu itu "menurut dia" atau "sebagaimana yang ia tangkap". Peristiwa yang sama, jika dipahami oleh orang yang berbeda, sangat mungkin hasil pemahamannya juga berbeda. Bahkan peristiwa yang sama jika dihayati oleh orang yang sama namun dalam kurun waktu yang berbeda, sangat mungkin hasil penghayatannya juga berbeda. Peristiwa itu sendiri ‘tidaklah terjangkau' karena selalu saja ketika 'disentuh' dan dipahami orang, maka peristiwa tersebut menjadi “peristiwa menurut yang menyentuh atau yang memahaminya".

Pemahaman dengan menimbang konteks 'yang dipahami' dan pelacakan terhadap apa saja yang mempengaruhi sebuah pemahaman sehingga menghasilkan keragaman, itulah kiranya yang menjadi fokus hermeneutika. Pada awal "kebangkitannya kembali" di zaman modern, Hermeneutika dikenal sebagai gerakan eksegesis dikalangan gereja. Adalah F.D.E Schleier macher, yang dikenal sebagai "Bapak Hermeneutika Modern”, yang pertama kali berusaha membakukan Hermeneutika sebagai satu metode umum interprestasi yang tidak hanya terbatas pada kitab suci dan sastra; kemudian Wilhelm Dilthey menerapkannya sebagai metode sejarah, lalu Hans Georg Gadamer mengembangkannya menjadi 'filsafat', Paul Riceour menjadikan sebagai 'metode penafsiran fenomenologis-komprehensif'. ${ }^{10}$ Lain dari itu beberapa filosof post-strukturalis seperti Jurgen habermas, Jackques Derrida maupun Michel Foucaut, mengembangkan sebentuk 'kritik hermeneutik', yaitu menganalisis proses pemahaman manusia yang sering terjebak otoritarianisme, khususnya karena tercampurnya determinasi-determinasi sosial-budaya-psikologis dalam kegiatan

\footnotetext{
${ }^{9}$ Fahruddin Faiz. Hermeneutika al-Qur'an.(Yogyakarta: eLSAQ Press. 2005). Hlm.6

${ }^{10}$ Mengenai perkembangan historis dari Hermeneutika ini bisa dilihat antara lain dengan E. Sumaryono, Hermeneutik; Sebuah Metode Filsafat, (Yogyakarta: Kanisius, 1999).
} 
Pendekatan Hermeneutika Dalam Ilmu Tafsir...

memahami. Lain dari itu perlu pula disebut banyak tokoh lain yang memanfaatkan hermeneutika sebagai alat bedah bagi disiplin keilmuan masing-masing, khususnya para pengkaji ilmu-ilmu agama. ${ }^{11}$

Ada yang membagi hermeneutika menjadi dua, yaitu hermeneutical theory yang berisi aturan metodologis untuk sampai kepada pemahaman yang diinginkan pengarang (author), dan hermeneutical philosophy yang lebih mencermati dimensi filosofisfenomenologis pemahaman. Kalau hermeneutical theory memusatkan perhatian kepada bagaimana memperoleh makna yang tepat dari teks atau sesuatu yang dipandang sebagai teks, maka hermeneutical philosophy melangkah lebih jauh dengan menggali asumsiasumsi epistimologis dari penafsiran dan melangkah lebih jauh ke dalam aspek historisitas, tidak hanya dalam dunia pembacanya. Bagi hermeneutical philosophy "the question is not what we do or what we should do, but what happen beyond our willing and doing". ${ }^{12}$ Selain dua jenis hermeneutika ini Joseph Bleicher menambahkan satu lagi jenis hermeneutika, yaitu heremeneutika kritis. Klasifikasi terakhir ini disebut untuk menjadi wadah bagi kritik hermeneutik dari orang-orang seperti Habermas, Derrida dan yang lain seperti disebut di atas. $^{13}$

Untuk lebih memudahkan pemahaman tentang perbedaan jenis-jenis hermeneutika ini, ada baiknya secara definitive ditegaskan lagi ketiga perbedaan hermenutika ini: ${ }^{14}$

1. Hermeneutika yang berisi cara untuk memahami

Hermeneutika jenis pertama ini adalah hermeneutika teoritis.Dalam klasifikasi ini hermeneutika merupakan kajian penuntun bagi sebuah pemahaman yang akurat dan proposional.Bagaimana pemahaman yang komprehensif itu? Itulah pertanyaan utama dari hermeneutika teori.Tentu saja sebagaimana asumsi awal bahwa perbedaan konteks mempengaruhhi perbedaan pemahaman, maka hermeneutika dalam kelompok pertama ini merekomendasikan pemahaman konteks sebagai salah satu aspek yang harus dipertimbangkan untuk memperoleh pemahaman yang komprehensif. Selain pertanyaanpertanyaan seputar makna teks seperti bagaimana makna teks secara morfologis, taksis,

\footnotetext{
${ }^{11}$ Fahruddin Faiz. Hermeneutika al-Qur'an.(Yogyakarta: eLSAQ Press. 2005). Hlm.7

${ }^{12}$ Hans George Gadamer, Truth and Method (New York: the Seabury Press, 1975) hlm.xvi

${ }^{13}$ Fahruddin Faiz. Hermeneutika al-Qur'an.(Yogyakarta: eLSAQ Press. 2005). Hlm7

${ }^{14}$ Ibid. hlm.7
}

Falasifa, Vol. 10 Nomor 2 September 2019 | 72 


\section{Ummi Inayati}

leksikologis dan sintaksis; ${ }^{15}$ perlu pula pertanyaan-pertanyaan seperti dari siapa teks itu berasal? Untuk tujuan apa?, dalam kondisi apa dan bagaimana kondisi pengarangnya ketika teks tersebut disusun? Dan lain sebagainya. Orang-orang yang dapat dipandang sebagai pelopor dalam hermeneutika jenis kedua ini adalah Schleirmacher, W. Dilthey dan juga Emilio Betti.

2. Heremenutika yang berisi cara untuk memahami pemahaman

Hermeneutika jenis kedua ini melangkah lebih jauh ke dalam daratan filosofis, sehingga lebih dikenal sebagai hermeneutikaa filosofis. Dalam hermeneutika jenis kedua ini, fokus perhatiannya bukan lagi bagaimana agar bisa mendapatkan pemahaman yang komprehensif, tetapi lebih jauh mengupas seperti apa kondisi manusia yang memahami itu, baik dalam aspek psikologisnya, sosiologisnya, historisnya dan lain sebagainya termasuk dalam aspek-aspek filosofis yang mendalam seperti kajian terhadap pemahaman dan penafsiran sebagai pra-syarat eksistensial manusia. Heideger dan Gadamer bisa diletakkan sebagai representasi kelompok kedua ini. Ini berarti, hermeneutika dalam dimensi filosofis - mungkin lebih tepatnya; epistimologisnya dapat didefenesikan sebagai suatu "pemahaman terhadap pemahaman". Ibarat "cerita berbingkai" dalam dunia sastra, maka hermeneutika jenis ini adalah suatu pemahaman terhadap suatu pemahaman yang dilakukan seseorang dengan menelaah proses dan asumsi-asumsi yang berlaku dalam pemahaman tersebut, termasuk diantaranya konteks yang melingkupi dan mempengaruhi proses tersebut. Hal ini secara umum dilakukan setidaknya untuk dua tujuan: pertama untuk meletakkan hasil pemahaman yang dimaksud dalam porsi dan proporsi yang sesuai dan kedua, untuk melakukan suatu "produksi" makna baru dari pemahaman terdahulu tersebut dalam bentuk kontekstualisasi. Menariknya, pada gilirannya, pemahaman terhadap pemahaman ini akan juga menjadi objek pemahaman sebelumnya; demikianlah seterusnya proses semacam ini berlanjut tanpa harus terjadi overlapping dalam pemahaman.

3. Hermeneutika yang berisi cara untuk mengkritisi pemahaman

Hermeneutika jenis ketiga ini dapat dikatakan merupakan pengembangan lebih jauh dari hermeneutika jenis kedua, bahkan dapat dikatakan bahwa secara prinsipil objek

\footnotetext{
${ }^{15}$ Hasan Hanafi, Dialog Agama dan Revolusi, terj. Pustaka Firdaus, (Jakarta: Pustaka Firdaus, 1994), hlm. 18-
} 20 
Pendekatan Hermeneutika Dalam Ilmu Tafsir...

formal yang menjadi fokus kajiannya adalah sama. Yang membedakan hermeneutika jenis ketiga dengan hermeneutika jenis kedua adalah penekanan hermeneutika jenis ketiga ini terhadap determinasi-determinasi historis dalam proses pemahaman, serta sejauh mana determinasi-determinasi tersebut sering memunculkan alienasi, diskriminasi dan hegemoni wacana, termasuk juga penindasan-penindasan sosialbudaya-politik akibat pengguna otoritas pemaknaan dan pemahaman oleh kelompok tertentu. $^{16}$

Dengan prosedur kerja dan asumsi-asumsi semacam yang digambarkan di atas, maka hermeneutika bisa dikatakan bergerak dalam tiga horizon, yaitu horizon pengarang, horizon teks dan horizon penerima atau pembaca; sementara secara prosedural, langkah kerja hermeneutika itu menggarap wilayah teks, konteks dan kontekstualisasi, baik yang berkenaan dengan aspek operasional metodologisnya maupun dalam dimensi epistimologis penafsirannya. Hermeneutika jenis pertama dapat dikatakan menekankan proses pemahaman dalam dua horizon, yaitu dalam horizon pengarang dan horizon teks; sementara hermeneutika jenis kedua dan ketiga memfokuskan kepada horizon pembaca. Hermeneutika jenis pertama berusaha melacak bagaimana teks tersebut dipahami oleh pengarangnya dan kemudian pemahaman pengarang itulah dipandang sebagai pemaknaan yang paling akurat terhadap teks, sementara hermeneutika jenis kedua dan ketiga lebih melihat bagaimana teks itu dipahami oleh pembaca, karena pengarang tidak mampu menyetir pemahaman pembaca terhadap teks yang telah diproduksinya, sehingga teks pada dasarnya mutlak milik pembacanya untuk dipahami dan dihayati seperti apapun keinginannya. ${ }^{17}$

Disisi lain, tiga klasifikasi menunjukkan bahwa meskipun tidak semua pemahaman itu berpola hermeneutis, dalam arti tidak semua pemahaman yang selain melihat teks (objek kajiannya) juga melihat konteks; namun setiap pemahaman bisa dibaca dan dianalisis secara hermeneutis. Kenyataan ini sering membuat bingung para peminat heremenutika,misalnya ketika mereka melihat adanya kajian hermeneutika terhadap teks-teks klasik yang tidak mengenal hermeneutika atau kajian hermeneutik terhadap pemikiran-pemikiran yang bahkan anti hermeneutik. Teks-teks klasik atau pemikiran-

\footnotetext{
${ }^{16}$ Fahruddin Faiz. Hermeneutika al-Qur'an.(Yogyakarta: eLSAQ Press. 2005). Hlm.10

${ }^{17}$ Fahruddin Faiz. Hermeneutika al-Qur'an.(Yogyakarta: eLSAQ Press. 2005). Hlm11

Falasifa, Vol. 10 Nomor 2 September 2019 | 74
} 


\section{Ummi Inayati}

pemikiran yang anti-hermeneutik tersebut jelas tidak berpola hermeneutis, karena mungkin pengarangnya ketika menyusun teks tersebut tidak menimbang konteksnya; namun produk dari upaya yang tidak hermeneutis tersebut bisa dikaji secara hermeneutis dengan mempertanyakan mengapa bisa muncul teks yang tidak hermeneutis tersebut?Apa yangmenjadi latar belakangnya? Faktor apa saja yang mempengaruhinya, dan lain sebagainya. Jawaban dari pertanyaan-pertanyaan ini jelas akan menghasilkan sebuah teks baru yang bercorak hermeneutis. ${ }^{18}$

\section{B. Hermeneutika terhadap Ilmu Tafsir Al Quran}

Ada dua hal yang tidak bisa dilepaskan dalam kehidupan manusia; dua hal itu menjadi garis demarkasi yang membedakan manusia dari segala entitas kehidupan lainnya di muka bumi ini. Dua hal yang dimaksud adalah memahami dan menafsirkan. Berkaitan dengan aktivitas memahami dan menafsirkan ini, dalam sejarah intelektual manusia banyak ditemui para tokoh di bidang keahliannya masing-masing yang berusaha merumuskan apa dan bagaimana kondisi dan cara memahami yang akurat,tepat, layak dan benar. Berbagai teori, konsep dan disiplin keilmuan pun muncul khusus untuk mengurusi bidang ini; satu diantaranya adalah Hermeneutika. ${ }^{19}$

Beberapa tahun terakhir ini, kajian-kajian mengenai Hermeneutika maupun kajiankajian yang memanfaatkan Hermeneutika sebagai pendekatan semakin "populer" dan dipakai oleh para ilmuwan dari berbagai bidang kajian, seperti para kritikus sastra, sosiolog, sejarawan, antropolog dan filosof. Popularitas hermeneutika ini harus dikatakan mengiringi perubahan paradigma berpikir manusia secara umum, khususnya yang terjadi dalam dunia ilmiah akademik.Sebagaimana diketahui, baik dalam era Yunani dikenal kosmosentris (berpusat pada alam), era skolastik terkenal dengan nularnya yang teosentris (berpusat kepada Tuhan) dan era modern terbukti bercorak antroposentris (berpusat pada manusia). Biasanya sebuah paradigma berpikir yang serba sentris ini membawa implikasi hegemoni dan otoritarianistik, yaitu dominasi pemaknaan dan kebenaran oleh ide-ide dan

\footnotetext{
${ }^{18}$ Ibid. hlm.10
}

${ }^{19}$ Ibid. hlm. 1 
Pendekatan Hermeneutika Dalam Ilmu Tafsir...

pikiran yang sejalur dengan sentris yang berlaku, sehingga segala orientasi berpikir yang lain menjadi terpimggirkan dan tersubordinasi. ${ }^{20}$

Seiring dengan munculnya berbagai kritik terhadap modernisme, paradigm ini terpusat mulai dipertanyakan.Secara komulatif kritik-kritik tersebut dapat dikatakan melahirkan paradigm baru yang biasa disebut sebagai pasca-modern.Paradigma baru ini secara umum membawa isu besar 'anti-sentris'. ${ }^{21}$ Ada dua kesadaran utama yang menjadi pemicu paradigm baru ini, yaitu kesadaran kontekstualitas dan kesadaran progresifitas.Kesadaran kontekstualitas berarti kesadaran bahwa setiap orang, setiap kelompok orang atau setiap komunitas social budaya tertentu berperilaku dan bernalar sesuai dengan konteks kehidupannya; baik konteks historis, social-budaya-politik, maupun konteks psikologis. Konteks inilah yang dipandang menemukan apa yang mereka serap (internalisasi) dan apa yang mereka ekspresikan melalui pikiran dan perbuatan (eksternalisasi). Sementara itu kesadaran progresifitas berarti kesadaran akan dinamika dan perkembangan dalam kehidupan. Kesadarn progresifitas ini mengasumsikan bahwa kehidupan manusia itu tidak statis atau mandeg, tetapi senantiasa terjadi proses dialogis dan dialektis antar variabelnya yang pada gilirannya memunculkan sesuatu yang baru, atau setidaknya sesuatu yang berbeda. Meskipun mungkin tidak persis seperti ramalan Hegel bahwa perkembangan tersebut secara umum bergerak kearah yang lebih rasional dan lebih baik, namun yang jelas perkembangan dan perubahan itu ada dan terjadi, bahkan terus menerus. $^{22}$

Kedua kesadaran di atas pada gilirannya akan membawa sebuah asumsi yang menjadi focus utama para tokoh pasca-modern, 'pluralitas'. Kesimpulan bahwa kehidupan itu plural didasarkan pada fakta bahwa konsep hidup manusia itu senantiasa dinamis.Asumsi pluralitras ini mengimplikasikan sebuah kritik kepada paradigm berpikir sebelumnya serba sentris.Dengan meyakini asumsi pluralitas ini maka muncul tuntutan untuk mengakui bahwa tidak ada satu pun teori, konsep maupun sentris yang mampu mengakomodasi secara total dan mampu memberikan analisis holistic yang bisa mencakup segala dimensi kehidupan manusia yang kompleks. Setiap teori, setiap konsep, juga setiap pemahaman dan penafsiran terhadap kehidupan dan segala aspeknya mengandung sebentuk

${ }^{20}$ Ibid. hlm. 2

${ }^{21}$ Ibid.

${ }^{22}$ Ibid. hlm. 3

Falasifa, Vol. 10 Nomor 2 September 2019 | 76 


\section{Ummi Inayati}

reduksi, yaitu 'pemangkasan' realitas karena keterbatasan perspektif uuntuk mampu mengakomodasi sebuah kenyataan hidup. ${ }^{23}$

Berdasarkan asumsi inilah selanjutnya hermeneutika menemukan posisinya yang strategis, karena sebagai sebuah disiplin kajian yang menggarap wilayah pemahaman dan penafsiran manusia terhadap realitas hidupnya - dalam aspek apapun--,hermeneutika sejak awal sangat menimbang pluralitas. Dengan menimbang asumsi pluralitas ini hermeneutika sejak awal menegaskan bahwa konteks dalam setiap horizon kehidupan manusia, baik pada dataran individu, social, budaya maupun politik, sangat 'bermain' dan mempengaruhi pola pemahaman dan juga ekspresi hasil pemahaman tersebut. ${ }^{24}$ Hermeneutika dan ilmu tafsir al-Qur'an Meskipun Hermeneutika bisa dipakai sebagai alat untuk "menafsirkan” berbagai bidang kajian keilmuan, melihat sejarah kelahiran dan perkembangannya, harus diakui bahwa peran Hermeneutika yang paling besar adalah dalam bidang ilmu sejarah dan kritik teks, khususnya kitab suci. Mengenai hal ini Roger Trigg, sebagaimana dikutip oleh Komaruddin Hidayat dalam bukunta Memahami Bahasa Agama berkata: ${ }^{25}$

The Paradigm for hermeneutics is the interpretation of a tradional text, where the problem must always be how we can come to understand in our pwn context something which was written in a radically different situation. ${ }^{26}$

Sebagai sebuah tawaran metodologi baru bagi pengkajian kitab suci, keberadaan hermeneutika pun tidak bisa dielakkan dari dunia kitab suci al-Qur'an.Menjamurnya berbagai literature Ilmu Tafsir kontemporer yang menawarkan hermeneutika sebagai variabel metode pemahaman al-Qur'an menunjukkan betapa daya tarik hermeneutika memang luar biasa. Hassan Hanafi dalam tulisannya Religious Dialogue and Revolution menyatakan bahwa Hermeneutik itu tidak sekedar ilmu interpretasi atau teori pemahaman, tetapi juga berarti ilmu yang menjelaskan penerimaan wahyu sejak dari tingkat perkataan sampai ke tingkat dunia. Ilmu tentang proses wahyu dari huruf sampai kenyataan, dari logos sampai praksis dan juga transformaaasi wahyu dari pikiran Tuhan kepada kehidupan manusia. $^{27}$

\footnotetext{
${ }^{23} \mathrm{Ibid}$.

${ }^{24}$ Ibid. hlm. 4

${ }^{25}$ Ibid. hlm. 12

${ }^{26}$ Komaruddin Hidayat, Memahami Bahasa Agama (Jakarta; Paramadina, 1996), hlm.161

${ }^{27}$ Hasan Hanafi, Dialog Agama dan Revolusi, hlm.1
} 
Pendekatan Hermeneutika Dalam Ilmu Tafsir...

Sebenarnya, term khusus yang digunakan untuk menunjuk kegiatan interpretasi dalam wacana keilmuan Islam adalah "tafsir" ${ }^{28}$ Kata yang asalnya dalam bahasa Arab fassara atau fasara ini digunakan secara teknis dalam pengertian eksegesis di kalanagan orang Islam dari abad ke-5 hingga sekarang. ${ }^{29}$ Sementara itu istilah Hermeneutik sendiri dalam sejarah keilmuan Islam, khususnya tafsir al-Quran klasik, tidak ditemukan. Istilah Hermeneutika ini kalau melihat sejarah perkembangan Hermeneutika Modern mulai popular beberapa decade terakhir, khususnya dengan perkembangan pesat teknologi informasi dan juga the rise of education yang melahirkan banyak intelektual muslim kontemporer. Meski demikian, menurut Farid Esack dalam bukunya Qur'an: Pluralism and Liberation, praktek Hermeneutik sebenarnya telah dilakukan oleh Umat Islam sejak lama, khususnya ketika menghadapi al-Quran. Bukti dari hal itu adalah: ${ }^{30}$

1. Problematika Hermeneutik itu senantiasa dialami dan dikaji, meski tidak ditampilkan secara definitive. Hal ini terbukti dari kajian-kajian mengenai asbabunnuzul dan nasakh-masukh.

2. Perbedaan antara komentar-komentar yang actual terhadap al-Qur'an (tafsir) dengan aturan, teori atau metode penafsiran telah ada sejak mulai munculnya literaturliteratur tafsir yang disusun dalam bentuk ilmu tafsir.

3. Tafsir tradisional itu selalu dimasukkan dalam kategori, misalnya tafsir syi'ah, tafsir mu’tazilah, tafsir hokum, tafsir filsafat, dan lain sebagainya. Hal itu menjunjukkan adanya kesadaran tentang kelompok-kelompok tertentu, ideologi-ideologi tertentu , periode-periode tertentu, maupun horizon-horison social tertentu dari tafsir. ${ }^{31}$

Ketiga hal ini jelas menunjukkan adanya kesadaran akan historisitas pemahaman yang berimplikasi kepada pluralitas penafsiran. Oleh karena itu meskipun tidak secara definitif, dapat dikatakan corak hermeneutic yang berasumsi dasar pluralitas pemahaman ini sebenarnya telah memiliki bibit-bibitnya dalam ulumul Qur'an klasik. ${ }^{32}$

\footnotetext{
${ }^{28}$ Tafsir di kalangan Umat Islam biaa dipahami sebagai satu disiplin ilmu yang membahas mengenai segala hal yang berkaitan dengan al Qur'an dalam aspek memahami maksud yang dikandungnya sesuai dengan kemampuan manusia. Lihat antara lain dalam Abu al-Fadl Jalal al-Din Abd al-Rahman Abu Bakar al-Suyuti, Al-Tahbir fi 'ilm al-Tafsir, (Beirut; Dar al-Kutub al-'Ilmiyyah, 1988), hlm.15

${ }^{29}$ Sebenarnya jika dilihat dari arti terminologisnya, kata Hermeneutika itu setara tidak saja dengan kata "tafsir", tetapi juga dengan kata ta'wil, syarh dan juga bayan.

${ }^{30}$ Fahruddin Faiz. Hermeneutika al-Qur'an.(Yogyakarta: eLSAQ Press. 2005). Hlm.13

${ }^{31}$ Farid Esack, Qur'an;Pluralism \& Liberation (Oxford: One World, 1997) hlm.161

${ }^{32}$ Fahruddin Faiz. Hermeneutika al-Qur'an.(Yogyakarta: eLSAQ Press. 2005). Hlm.14

Falasifa, Vol. 10 Nomor 2 September 2019 | 78
} 


\section{Ummi Inayati}

Operasional Hermeneutika Modern dakam penafsiran al-Qur'an bisa dikatakan dirintis oleh para penmbaharu muslim; seperti di India dikenal dengan Ahmad Khan, Amir Ali dan Ghulam Ahmad Parves, yang berusaha melakukan demitologisasi ${ }^{33}$ konsep-konsep dalam al-Qur'an yang dianggap bersifat mitologis, seperti mengenai mukjizat dan hal-hal gaib. Di Mesir muncul Muhammad Abduh yang secara operasioal melakukan operasi Hermeneutik dengan bertumpu pada analisis social kemasyarakatan.Meskipun demikian, rumussan metodologis mereka ini tidak sistematis dan tidak terlalu jelas. ${ }^{34}$

Dalam decade 1960 sampai 1970-an, muncul tokoh-tokoh yang mulai serius memikirkan persoalan metodologi tafsir ini. Hassan Hanafi mempublikasikan tiga karyanya yang bercorak Hermeneutik; yang pertama berkaitan dengan rekonstruksi ilmu ushul fiqih, yang kedua berkaitan dengan Hermeneutika feneomenologis dalam menafsirkan fenomena keagamaan, dan yang ketiga berhubungan dengan kajian kritis terhadap Hermeneutika eksistensial dalam kerangka penafisiran Perjanjian Baru. ${ }^{35}$ Mohammad Arkoun dari Aljazair menelorkan idenya mengenai ‘cara baca' semiotic terhadap al-Qur'an, dan Fazlur Rahman merumuskan metode Hermeneutika yang sistematik terhdap al-Qur'an dan dikenal sebagai "double movement". 36

Dewasa ini telah banyak pemerhati al-Qur'an yang melakukan kritik historis dan linguistic yang menjadi ciri khas Hermeneutika.Tulisan-tulisan yang menyangkut bidang ini banyak bermunculan, baik dari kalangan outsider maupun dari kalangan Umat Islam sendiri. Diantara tulisan-tulisan tersebut misalnya Qur'anic Hermeneutic: The Views of alTabari and Ibn Katsir karya Jane Mc Auliffe yang menekankan pada metode tafsirnya dan sedikit pada horizon sosialnya, ${ }^{37}$ lalu tulisan Azim Nandji yang membahas tentang teori ta’wil dalam tradisi keilmuan Isma'ili yang banyak membantu dalamkritik sastra, ${ }^{38}$ juga

\footnotetext{
${ }^{33}$ Demitologisasi disini bukan berarti membuang sama sekali cerita-cerita yang dianggap mitos karena dianggap sekedar dongeng-dongeng, tetapi berarti mempersepsikan mitos sebagai ungkapan simbolis mengenai satu realitas dengan mempergunakan gambaran-gambaran, kiasan-kiasan dan lukisan-lukisan. Dengan demikian persoalannya bukanlah bagaimana melenyapkan mitos tetapi bagaimana menafsirkannya secara eksistensial.

${ }^{34}$ Fahruddin Faiz. Hermeneutika al-Qur'an.(Yogyakarta: eLSAQ Press. 2005). Hlm.14

${ }^{35}$ Hassan Hanafi, Muqaddimah fi 'Ilm al-Istighrab, (Kairo: Dar al-Faniyah, 1991). Hlm.84-86

${ }^{36}$ Fahruddin Faiz. Hermeneutika al-Qur'an.(Yogyakarta: eLSAQ Press. 2005). Hlm.15

${ }^{37}$ Lihat Jane Mc Mauliffe, “Qur'anic Hermeneutics: The Views of al-Tabari and The Ibn Katsir” dalam A. Rippin (ed.), Approaches to the History of the Quran, (Oxford: Clarendon, 1998). Hlm.46-62

38 Azim Nanji, "Toward a Hermeneutic of Qur'anic and Other Narrative of Isma'ili Thought" dalam Richard C. Martin (ed.), Approaches to Islam in Relegious Studies (Tucson: The University of Arizona Press). Hlm.164-174
} 
Pendekatan Hermeneutika Dalam Ilmu Tafsir...

Nasr Hamid Abu Zard yang dengan intensif menggeluti kajian Hermeneutik dalam tafsir klasik. $^{39}$

Apa yang dilakukan oleh Fazlurrahman, Arkoun, Abu Zayd yang lainnya adalah contohcontoh bagaimana "mengolah" al-Quran dengan Hermeneutika. Hermeneutika, sebagaimana disebut di atas, pada dasarnya merupakan satu metode penafsiran yang berangkat dari analisa bahasa dan kemudian melangkah kepada analisa konteks, untuk selanjutnya "menarik" makna yang didapat ke dalam ruang dan waktu saat pemahaman dan penafsiran tersebut dilakukan. Jika pendekatan ini dipertemukan dengan kajian teks alQur'an, maka persoalan dan tema pokok yang dihadapi ada;ah bagaimana teks al-Qur'an hadir di tengah masyarakat, lalu dipahami, ditafsirkan, diterjemahkan dan didialogkan dengan dinamika realitas historisnya. ${ }^{40}$

Sehubungan dengan pendekatan hermeneutika modern terhadap al-Qur'an ini, maka perlu diperhatikan tiga hal yang menjadi asumsi dasar dalam penafsirannya, yaitu: ${ }^{41}$

1. Para penafsir itu adalah manusia

Siapapun orangnya yang menafsirkan teks kitabsuci itu, ia tetapkan manusia biasa yang lengkap dengan segala kekurangan, kelebihannya dan kesementaraannya karena terikat oleh ruang dan waktu tertentu. Dengan asumsi ini diharapkan bisa dimengerti bahwasanya manusia itu tidak akan bisa melepaskan diri dari ikatan historis kehidupan dan pengalamannya, dimana ikatan tersebut sedikit banyak akan membawa pengaruh dan mewarnai corak penafsirannya. Asumsi ini dimaksudkan untuk tidak memberikan vonis "mutlak" benar atau salah kepada suatu penafsiran, namun lebih mengarah untuk melakukan pemahaman dan analisa yang kritis terhadap suatu penafsiran. Para penafsir adalah manusia yang membawa "muatanmuatan" kemanusiaan masing-masing. Setiap generasi muslim sejak masa Nabi Muhammad, sambil membawa "muatan"-nya itu, telah memproduksi komentarkomentar mereka sendiri terhadap al-Qur'an. Tidaklah mengherankan jika akhirnya ada beragam interpretasi dari setiap generasi. ${ }^{42}$

\footnotetext{
${ }^{39}$ Lihat antara lain dalam Nasr Hamid Abu Zayd, Isykaliyat al-Qira'at wa 'Aliyat al-Ta'wil. (Beirut; alMarkaz al-Saqafi al-'Arabi, 1994)

${ }^{40}$ Fahruddin Faiz. Hermeneutika al-Qur'an.(Yogyakarta: eLSAQ Press. 2005). Hlm.15

${ }^{41}$ Ibid. hlm. 16

${ }^{42}$ Farid Esack, Qur'an Pluralism and Liberation. Hlm.50

Falasifa, Vol. 10 Nomor 2 September 2019 | 80
} 


\section{Ummi Inayati}

2. Penafsiran itu tidak tidak dapat lepas dari bahasa, sejarah dan tradisi

Segala aktifitas penafsiran pada dasarnya merupakan satu partisipasi dalam proses historis-linguistik dan tradisi yang berlaku, dimana partisipasi ini terjadi dalam ruang dan waktu tertentu. Pergulatan Umat Islam sengan al-Quran juga berada dalam "kurungan" ini.Seseorang tidak mungkin bisa melepaskan diri dari bahasa, budaya dan tradisi dimana mereka hidup.Para pemikir reformis sering menyatakan bahwasanya kritis yang terjadi di dunia Islam serta ketidakmampuan umat Islam untuk memberikan satu kontribusi yang berguna bagi dunia kontemporer adalah dikarenakan tradisi.Jalan keluar yang dianjurkan oleh para reformis itu seringkali adalah dengan meninggalkan ikatan-ikatan dan "kembali kepada al-Qur'an".Pernyataan tersebut sebenarnya tidak selaras dengan fakta bahwasanya satu penafsiran itu tidak bisa secara sepenuhnya mandiri berdasarkan teks, tetapi pasti terkait dengan muatan historisnya, baik muatan historis saat teks itu muncul dan saat teks itu ditafsirkan. ${ }^{43}$

3. Tidak ada teks yang menjadi wilayah bagi dirinya sendiri

Nuansa sosio-historis dan linguistic dalam pewahyuan al-Qur'an itu Nampak dalam isi, bentuk, tujuan dan bahasa yang dipakai al-Qur'an.Hal ini Nampak pula misalnya dalam perbedaan antara ayat-ayat makkiyah dan ayat-ayat madaniyah.Dalam hubungannya dengan proses pewahyuan, bahasa da nisi di satu sisi, serta dengan komunitas masyarakat yang menerimanya di satu sisi yang lain, al-Qur'an tidaklah "unik". Wahyu selalu saja merupakan komentar terhadap setidaknya harus dipahami dalam kerangka kondisi masyarakat tertentu dimana wahyu itu turun. ${ }^{44}$

\section{Perspektif Hermeneutika terhadap al-Qur'an}

Khazanah Ulumul Qur'an sebagai sebentuk metodologi untuk menggarap wilayah penafsiran dan pemaknaan terhadap al-Qur'an harus diakui memiliki tingkat sofistikasi yang luar biasa.Sifat luar biasa dari khazanah Ulumul Qur'an ini terbukti dan berlimpahnya karya tafsir dengan berbagai pola, mulai tahlili sampai maudhu'idan mulai yang sekedar

\footnotetext{
${ }^{43}$ Ibid. hlm.77
}

${ }^{44}$ Ibid. hlm.33 
Pendekatan Hermeneutika Dalam Ilmu Tafsir...

menafsirkan dengan mencari sinonim kata dan ayat hingga yang melakukan ta'wil secara intuitif dan menafsirkan secara ilmiah.Kenyataan ini mau atau tidak telah membuktikan komprehensifnya Ulumul Qur'an tersebut dalam menjembatani jarak antara mufassir dangan al-Qur'an sehingga melahirkan bernagai khazanah tafsir. Sampai disini mungkin kemudian orang akan menyimpulkan bahwa sebenarnya Ulumul Qur'an saja telah cukup dan tidak perlu lagi tambahan-tambahan metodologi baru semisal hermeneutika ini. ${ }^{45}$

Apabila melihat asumsi-asumsi dasar hermeneutika diatas, yaitu perhatian tidak saja kepada teks, namun juga konteks, sebenarnya beberapa perangkat dan variabel Ulumul Qur'an Klasik telah menunjukkan orientasi kearah tersebut.Tema-tema seperti MakkiMadani, Asbabun Nuzul, juga Nasikh mansukh secara langsung atau tidak menunjukkan perhatian adanya perbedaan konteks yang mempengaruhi pemaknaan.Sampai di titik ini klaim bahwa Ulumul Qur'an masih memadai untuk mengolah dimensi pemaknaan terhadap al-Qur'an harus diakui memiliki relevansi. ${ }^{46}$

Berdasarkan ketiga jenis Hermeneutika sebagaimana disebut di atas, maka bisa dikatakan bahwa Ulumul Qur'an tersebut telah memenuhi kriteria hermeneutika jenis pertama, yaitu telah memiliki kesadaran akan pentingnya konteks sebagai salah satu cara untuk menggali makna dari teks. Oleh karena itu harus dikatakan bahwa secara hermeneutic Ulumul Qur'antelah bergerak on the right track.Meskipun demikian, kesadaran konteks saja tidaklah cukup. Kesadaran konteks hanya akan membawa seseorang ke 'masa-lalu', kemana dimana sebuah teks dilahirkan, apa tujuan 'pengarang'-nya dan seperti apa pemaknaan para pembaca teks yang menjadi audiens pertama teks. Kesadaran konteks saja dan mencukupkam diri dengan pemaknaan dan pemahaman generasi masa lalu terhadap teks, hanya akan membawa seseorang kepada keterasingan dari aspek ruang dan waktu dimana dia hidup saat ini. Dalam bahasa hermeneutika, dengan kesadaran konteks saja yang terjadi hanyalah sekedar 'reproduksi' makna lama ke dalam ruang dan waktu masa kini. Mungkin saja dalam aspek tertentu pemaknaan lama ini masih relevan dan

\footnotetext{
${ }^{45}$ Fahruddin Faiz. Hermeneutika al-Qur'an.(Yogyakarta: eLSAQ Press. 2005). Hlm.18

${ }^{46}$ Ibid. hlm. 18
}

Falasifa, Vol. 10 Nomor 2 September 2019 | 82 


\section{Ummi Inayati}

sesuai untuk diaplikasikan, ${ }^{47}$ namun dalam banyak hal bisa dipastikan akan terjadi pemaknaan dan pemahaman yang mis-placed atau a-historis. ${ }^{48}$

Untuk mengatasi keterbatasan pemahaman yang berhenti kepada konteks ini adalah dengan menambahkan variabel kontekstualisasi, yaitu menumbuhkan kesadaran akan kekinian dan segala logika serta kondisi yang berkembang di dalamnya. Variabel kontekstualisasi yang dimaksud adalah perangkat metodologis yang bisa menjawab pertanyaan 'bagaimana agar teks yang diproduksi dan berasal dari masa lalu bisa dipahami dan bermanfaat untuk masa kini?". Dalam istilah jargonal yang sering disebut orang berkaitan dengan al-Qur'an, pertanyaannya mungkin sebagai berikut: 'bagaimana caranya agar al-Qur'an shahih li kulli zaman wa makan'?, bagaimana caranya agar al-Qur'an bisa applicable untuk segala ruang dan waktu, dan tidak hanya kompatibel untuk ruang dan waktu ketika teks tersebut muncul pertama kali. ${ }^{49}$

Menarik untuk melihat ternyata banyak manfaat al-Qur'an, bahkan sejak zaman para pembaharu, yang memiliki kesadaran kontekstualisasi ini.Sebut saja misalnya Muhammad Abduh dengan Tafsir Al-Manar-nya yang bercorak Adab 'Ijtima'imaupun dari berbagai tafsir iliah yang mencari kesesuaian ayat al-Qur'an dengan teori-teori sains modern seperti karya Tafsir Thantawi Jawhari.Namun ternyata, tafsir-tafsir yang sangat kontekstual pada jamannya tersebut harus dikatakan memiliki kelemahan dalam kesadarn historis; tepatnya, tafsir-tafsir tersebut sering mengabaikan kesadarn konteks.Tafsir-tafsir ini dapat dikatakan merupakan representasi dari model hermeneutika filosofis murni ala Gadamerian, karena implisit dalam tafsir-tafsir tersebut sebuah asumsi bahwa teks adalah sesuatu yang otonom dan independen, sehingga merupakan preogratif pembacanya untuk menafsirkan teks-teks tersebut sesuai ideal mereka.Lenyapnya kesadaran konteks dari tafsir-tafsir yang lebih melihat aspek kontekstualisasi ini tentu saja memiliki kelemahan dari aspek teologis, yaitu tuntutan bagi seorang yang beragama untuk tidak keluar dari asumsi-asumsi dan doktrin-doktrin keimanan serta ajaran-ajaran keutamaan yang digariskan oleh Tuhan sejak era Sang Pembawa Risalah hingga saat ini dalam bentuk teks kitab suci. Mengabaikan sama sekali konteks awal pemaknaan teks kitab suci

\footnotetext{
${ }^{47}$ Kemungkinan ini apabila dikaitkan langsung dengan Al-Qur'an biasanya berkaitan dengan hal-hal yang sifatnya vertical-ritual, yaitu dalam tata peribadatan formal, seperti shalat, puasa dan lain sejenisnya.

${ }^{48}$ Fahruddin Faiz. Hermeneutika al-Qur'an.(Yogyakarta: eLSAQ Press. 2005). Hlm.19

${ }^{49}$ Ibid. hlm. 20
} 
Pendekatan Hermeneutika Dalam Ilmu Tafsir...

mengimplikasikan a-historisitas dalam pemaknaan serta mengandung bahaya 'keluar dari maksud dan spirit teks yang sebenarnya'. 50

Sampai disini harus ditegaskan bahwa jalur teks-konteks-kontekstualisasi hendaknya diaplikasikan secara dialektis-dialogis dan berkesinambungan. Dengan secara intensif mendialogkan ketiga aspek tersebut diharapkan seorang mufassir selain mampu menaangkap tujuan utama dan spirit teks sehingga tidak ada a-historis, juga mampu mengaplikasikan pemahamannya dalam realitas kekinian, sehingga tidak a-sosial, tidak terasing dari ruang dan waktunya. Dapat dikatakan dalam aspek dialegtika teks-konteks dan kontekstualitasasi inilah terletak kelemahan besar kitab-kitab tafsir klasik.Ada kitab tafsir yang cenderung melihat teks saja, sehingga melahirkan pemaknaan yang harfiah belaka.Ada tafsir yang cenderung melihat konteks saja, sehingga melahirkan tafsir yang hanya melihat ideal-ideal pemaknaan masa lalu. Ada tafsir yang hanya merumuskan cara mengaplikasikan al-Qur'an dalam kehidupan kontekstual saja, sehingga terputus kaitannya dengan misi dan maksud awal al-Qur'an. ${ }^{51}$

Sumbangan paling berharga dari hermeneutika dan dapat dikatakan membawa sebuah perspektif baru dalam Ilmu Tafsir al-Qur'an adalah berasal dari para tokoh hermeneutika filosofis dan kritis. Sumbangan dari para tokoh ini secara umum adalah kesadaran akan adanya berbagai determinasi yang turut menentukan sebuah proses pemahaman, baik determinasi tersebut berasal dari wilayah social, budaya maupun politik, bahkan berasal dari wilayah psikologis. Kesadaran akan adanya determinasi-determinasi ini pada akhirnya akan mengeliminasi setiap pemahaman dan penafsiran yang merasa sebagai 'objektif' dan 'tanpa kepentingan-kepentingan tertentu, baik kepentingan untuk merebut wacana, kepentingan untuk mempertahankan status-quo agar pemaknaan dan pemahaman berjalan seperti sedia kala, atau setidaknya suatu keinginan agar apa yang dilakukannya adalah sesuatu yang benar. Kenyataan seperti ini tidak perlu dirisaukan selama perebutan pemaknaan dan kompetensi pemahaman tersebut berjalan dalam satu ruang politik yang sehat dan tidak ada pihak-pihak yang dengan kekuasaannya baik kekuasaan politik, social

\footnotetext{
${ }^{50}$ Ibid. hlm. 21

${ }^{51}$ Ibid.
}

Falasifa, Vol. 10 Nomor 2 September $2019 \mid 84$ 


\section{Ummi Inayati}

maupun budaya melakukan hegemoni pemaknaan dan meminggirkan segala pemaknaan lain yang tidak mendukungnya. ${ }^{52}$

Dari kesadaran ala hermeneutika kritis inilah nantinya diharapkam bisa muncul dan berkembang sikap inklusif dan toleran menghadapi keragaman.Harus diakui, kalangan umat beragama memiliki satu penyakit yang dapat dikatakan 'akut' dan menjadi sumber berbagai konflik dikalangan mereka sendiri, yaitu truth claim.Truth Claim ini terjadi ketika seseorang atau sekelompok orang menyatakan bahwa 'miliknya', pemikirannya, idenya, atau pandangannyalah yang paling benar, dan yang lain salah. Dalam duia penafsiran, truth claim ini Nampak dalam bentuk sikap apriori dan memandang bahwa penafsiran dan pemahamannyalah yang paling benar, dan 'yang lain' adalah salah. Disinilah kiranya Hermeneutika memberikan pelajaran bahwa sebenarnya setiap ide, pemikiran maupun penafsiran itu sangat dipengaruhi oleh konteks dan misi serta kepentingan dari sang penafsir; sehingga sangat tidak bijaksana untuk menyalahkan 'yang lain' dan membenarkan dirinya sendiri secara apriori, karena betapapun adanya, baik pikiran 'yang lain' maupun pikiran sendiri itu sangat ditentukan oleh konteks masing-masing. Setiap pemahaman pasti ada sisi-sisi kebenaran namun juga tidak mungkin sempurna dan memiliki aspek-aspek kelemahan dan kesalahan.Yang dapat dilakukan oleh setiap orang termasuk umat beragama, hanyalah berkarya dan berperilaku sebaik mungkin sesuai dengan kebenaran yang diyakininya, sekaligus berlomba secara adil dan fair dengan 'yang lain' sebaikbaiknya, dalam kebaikan. ${ }^{53}$

\section{Hasil diskusi}

Contoh tentang "hermeneutika yang berisi cara untuk memahami". Adalah lafadz "Bismillahirrahmanirrahim" pada ayat pertama surat al Fatihah menjelaskan dari perspektif hermeneutika adalah seorang hamba (manusia) tidak bisa mengakui sesuatu jika tanpa adanya Rahmatnya Allah. Manusia dalam melakukan perbuatan apapun tidak lepas dengan rahmat yang telah diberikan Allah kepada setiap hambanya. Kemudian lafadz "ar Rahmaan” dikaitkan dengan lafadz/ayat sebelumnya.

\footnotetext{
${ }^{52}$ Ibid.

${ }^{53}$ Ibid. hlm. 23
} 
Pendekatan Hermeneutika Dalam Ilmu Tafsir...

Contoh tantang "hermenutika yang berisi cara untuk mengkritisi pemahaman". Maksudnya adalah misalnya ada seorang mufasir yang telah melakukan penafsiran terhadap ayat al-Qur'an lalu jika dilihat menggunakan perspektif hermeneutika melihat apakah apa yang telah ditafsirkan itu benar atau salah. Jadi bisa dikatakan bahwa hermeneutika melihat lebih luas dan terjadi proses asosiasi dengan pesan yang dibawa.

\section{PENUTUPAN}

\section{A. Kesimpulan}

Kata Hermeneutika berasal dari bahasa Yunani hermeneuein yang berarti "menafsirkan". Hermeneutika adalah "proses mengubah sesuatu atau situasi ketidaktahuan menjadi tahu dan mengerti”. pembagian hermeneutic ada 3 yaitu hermeneutical theory, hermeneutical philosophy dan hermeneutical kritic. Untuk lebih memudahkan pemahaman tentang perbedaan jenis-jenis hermeneutika ini, ada baiknya secara definitive ditegaskan lagi ketiga perbedaan hermenutika ini: (1) Hermeneutika yang berisi cara untuk memahami, (2) Heremenutika yang berisi cara untuk memahami pemahaman, (3) Hermeneutika yang berisi cara untuk mengkritisi pemahaman.Berdasarkan ketiga jenis Hermeneutika sebaga imana disebutkan, maka bisa dikatakan bahwa Ulumul Qur'an tersebut telah memenuhi kriteria hermeneutika jenis pertama, yaitu telah memiliki kesadaran akan pentingnya konteks sebagai salah satu cara untuk menggali makna dari teks. Sumbangan paling berharga dari hermeneutika dan dapat dikatakan membawa sebuah perspektif baru dalam Ilmu Tafsir al-Qur'an adalah berasal dari para tokoh hermeneutika filosofis dan kritis. Sumbangan dari para tokoh ini secara umum adalah kesadaran akan adanya berbagai determinasi yang turut menentukan sebuah proses pemahaman, baik determinasi tersebut berasal dari wilayah social, budaya maupun politik, bahkan berasal dari wilayah psikologis. Kesadaran akan adanya determinasi-determinasi ini pada akhirnya akan mengeliminasi setiap pemahaman dan penafsiran yang merasa sebagai 'objektif' dan 'tanpa kepentingankepentingan tertentu, baik kepentingan untuk merebut wacana, kepentingan untuk mempertahankan status-quo agar pemaknaan dan pemahaman berjalan seperti sedia kala, atau setidaknya suatu keinginan agar apa yang dilakukannya adalah sesuatu yang benar.

Dari kesadaran ala hermeneutika kritis inilah nantinya diharapkam bisa muncul dan berkembang sikap inklusif dan toleran menghadapi keragaman. 


\section{Ummi Inayati}

\section{B. Kritik dan Saran}

Pemakalah menyadari dalam penyusunan makalah ini banyak sekali kekurangan, oleh karena itu kritik dan saran sangat pemakalah harapkan.

Adapun saran yang pemakalah sampaikan kepada pemakalah yang akan menkaji lebih jauh lagi tentang materi ini adalah:

1. Menambah referensi yang terbaru

2. Menambah keterangan lebih banyak dan jelas

\section{DAFTAR PUSTAKA}

Azim Nanji, “Toward a Hermeneutic of Qur'anic and Other Narrative of Isma'ili Thought" dalam Richard C. Martin (ed.), Approaches to Islam in Relegious Studies. Tucson: The University of Arizona Press

Abu al-Fadl Jalal al-Din Abd al-Rahman Abu Bakar al-Suyuti. 1988. Al-Tahbir fi 'ilm alTafsir. Beirut; Dar al-Kutub al-'Ilmiyyah

Bauman, Zygmunt. 1978. Hermeneutics anda Social Sciences, New York: Columbia University Press

E. Palmer, Richard. 1969. Hermeneutics: Interpretation Theory in Schleiermacher, Dilthey, Heiddeger, and Gadamer. Evanson: Northwestern University Press

Esack, Farid. 1997. Qur'an;Pluralism \& Liberation. Oxford: One World

George Gadamer, Hans. 1975. Truth and Method. New York: the Seabury Press

Hanafi, Hassan. 1991. Muqaddimah fi 'Ilm al-Istighrab. Kairo: Dar al-Faniyah

Hanafi, Hasan. 1994. Dialog Agama dan Revolusi, terj. Pustaka Firdaus. Jakarta: Pustaka Firdaus

Jane Mc Mauliffe, 1998. 'Qur'anic Hermeneutics: The Views of al-Tabari and The Ibn Katsir" dalam A. Rippin (ed.), Approaches to the History of the Quran. Oxford: Clarendon Hardiman, F. Budi 1990. “Hermeneutik; Apa itu?” dalam Basis, XL, no.3 Hidayat , Komaruddin. 1996. Memahami Bahasa Agama. Jakarta; Paramadina Hossein Nashr ,Sayyed. 1969. Islamic Studies: Essay on Law and Society, Beirut: Libreirie Du Liban 
Pendekatan Hermeneutika Dalam Ilmu Tafsir...

Kurdi.2010. Hermeneutika Al-Qur'an dan Hadis.Yogyakarta: Sukses Offset

Nasr Hamid Abu Zayd. 1994. Isykaliyat al-Qira'at wa 'Aliyat al-Ta'wil. (Beirut; alMarkaz al-Saqafi al-'Arabi

Sumaryono, E. 1999.Hermeneutik; Sebuah Metode Filsafat, Yogyakarta: Kanisius 